\title{
SPRING CHICAGO
}

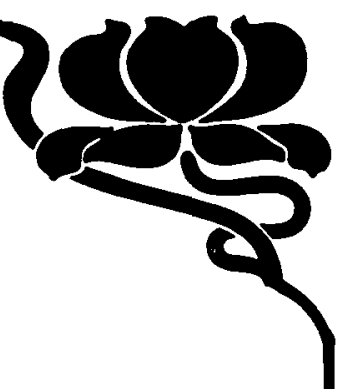

\section{CRITICAL UNDERSTANDING}

The Powers and Limits of Pluralism Wayne C. Booth

Through extended accounts of three major pluralists, Ronald S. Crane, Kenneth Burke, and M. H. Abrams, and shorter considerations of many others, Booth pursues the problems raised for anyone who rejects the search for some single, unitary, perhaps even "scientific" resolution to conflicting critical methods.

Cloth 352 pages $\$ 15.00$
February

\section{ON THE MARGINS OF DIScOURSE}

The Relation of Literature to Language

\section{Barbara Herrnstein Smith}

"Barbara Herrnstein Smith is one of a very few outstanding theorists of literature writing today, and her new book is a major contribution to the contemporary critical debate."-John M. Ellis, University of California, Santa Cruz

Cloth 248 pages $\$ 12.50$ November

\section{LITERATURE AGAINST ITSELF \\ Literary Ideas in Modern Society Gerald Graff}

In this wide-ranging inquiry, which involves current educational and social criticism as well as literature and criticism, Graff looks into the reasons why humanistic thinkers have argued themselves into such self-defeating positions: why writers and critics have defined the humanistic enterprise in ways that implicitly trivialize it.

$$
\text { Cloth } \begin{aligned}
& 256 \text { pages } \$ 14.00 \\
& \text { December }
\end{aligned}
$$

\section{THE ORIGIN OF CERTAINTY}

Means and Meanings in Pascal's Pensées

\section{Hugh M. Davidson}

"This is an important and distinguished piece of work; it may very well be for years to come the authoritative analysis of Pascal available in English." - Jules Brody, Queens College, CUNY

Cloth xii, 160 pages $\$ 12.00$ January

\section{ADVERBS, VOWELS, AND OTHER OBJECTS OF WONDER James D. McCawley}

"McCawley is a seminal, productive, important thinker in the field, and this book of essays is as much to be welcomed as was his Grammar and Meaning."- John Robert Ross, M. I. T.

Cloth 320 pages $\$ 20.00$ January

\section{THE UNIVERSITY OF CHICAGO PRESS}




\section{Writers and readings.}

Insisting that Emerson's biography is profoundly literary and his literature inextricably biographical, Joel Porte offers both fresh readings of Emerson's best work and a detailed account of how that work - from Nature to The Conduct of Life-grew directly from his life. \$15.95

REPRESENTATIVE MAN

Ralph Waldo Emerson in His Time Joel Porte

This pioneering work not only explores the intellectual links between the novelist of decorous detachment and the philosopher of feverish extremes but also illuminates a moment in cultural history which produced a radical new view of the relationship between life and art. $\$ 15.95$

\section{NIETZSCHE, HENRY JAMES, AND THE ARTISTIC WILL Stephen Donadio}

By adhering closely to the text - but not to traditional readings of it these lively, argumentative readings of Hamlet, Macbeth, Anthony and Cleopatra, and Coriolanus seek to liberate the Bard from hidebound criticism, approaching characters as people rather than literary constructs. $\$ 11.95$

\section{SHAKESPEARE'S MAGNANIMITY Four Tragic Heroes, Their Friends, and Families Wilbur Sanders and Howard Jacobson}

Blending memories and documents, Christopher Fry traces the intricate pattern of events that shaped his family history and his own formative years. Letters, diaries, and photographs enhance this intimate memoir of some remarkable people, not least the playwright himself. $\$ 13.95$

\section{CAN YOU FIND ME \\ - A Family History \\ Christopher Fry}

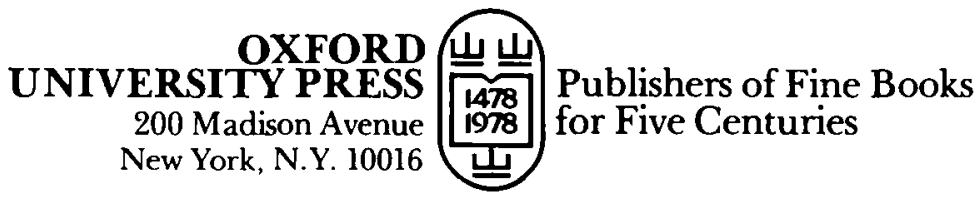

